\title{
THE FOREIGN LANGUAGE DISCIPLINE POTENTIAL IN EMOTIONAL INTELLECT FORMATION OF STUDENTS IN HIGHER EDUCATION TECHNICAL INSTITUTIONS
}

Summary. In the article it is proposed to explore optimal pedagogical technologies, methodical methods and means of forming emotional intelligence through the prism of the discipline «Foreign Language for Specific Purposes» for students in higher education technical institutions. The factors influencing young professionals successful socialization have been analyzed. The factors affecting employment and career growth have been investigated. The reasons for the competent specialist universal competencies formation and development in Foreign Language classes have been systematized. The issues that can lead to the successful socialization of young professionals have been highlighted.The future specialists foreign communicative competence formation has been analyzed. The most effective pedagogical technologies for enhancing emotional students have been suggested. Sharp contradictions among the complexity of the professional tasks faced by graduates of higher education institutions and the content of educational programs of vocational training have been investigated.

Keywords: emotional intelligence, technical education, competence-based approach, communicative method, universal competences.

Москаленко М.В.

Національний університет «Полтавська політехніка імені Юрія Кондратюка»

\section{ПОТЕНЦІАЛ ДИСЦИПЛІНИ ІНОЗЕМНОЇ МОВИ У ФОРМУВАННІ ЕМОЦІЙНОГО ІНТЕЛЕКТУ СТУДЕНТІВ ТЕХНІЧНИХ ЗАКЛАДІВ ВИЩОЇ ОСВІТИ}

Анотація. У статті пропонуеться дослідити оптимальні педагогічні технології, методичні методи та засоби формування емоційного інтелекту через призму навчальної дисципліни у студентів вищих навчальних закладів. Проаналізовано фактори, що впливають на успішну соціалізацію молодих фрахівців. Досліджено фрактори, що впливають на зайнятість та кар'єрний ріст майбутніх працівників. Систематизовано причини формування та розвитку універсальних компетентностей спеціалістів на заняттях іноземної мови. Висвітлено питання, які можуть призвести до успішної соціалізації молодих фрахівців. Проаналізовано формування у майбутніх спеціалістів зарубіжної комунікативної компетентності. Запропоновано найефективніші педагогічні технології для вдалого розвитку емоційного інтелекту студентів. Досліджено гострі суперечності між складністю професійних завдань, які стоять перед випускниками вищих навчальних закладів, та змістом освітніх програм професійної підготовки. Досліджено необхідність постійної самоосвіти студентів та профессіоналів та відсутність необхідних їм компетентностей для самоорганізації, самомотивації та самоконтролю. Вивчено потенціал дисципліни «Іноземна мова за профресійним спрямуванням», зокрема та в процесі впровадження освітніх програм у підготовку фахівців з технічних галузей. Запропоновано набір педагогічних та методичних ресурсів для вирішення проблем фрормування та розвитку емоційного інтелекту. Автором були обрані оптимальні педагогічні технології, методологічні методи та засоби формування емоційного інтелекту через призму дисципліни «Іноземна мова за професійним спрямуванням». Оригінальний авторський підхід корисний для фрахівців з викладання іноземних мов у технічних закладах вищої освіти. Автори статті наголошують, що студенти нового покоління повинні не лише володіти набором певних професійних знань, умінь та навичок, але й бути зрілими, відповідальними, творчими особистями 3 активною життевою позицією. Важливо враховувати цінний досвід, набутий під час закордонних відряджень педагогів та методистів у галузі викладання іноземних мов та використовувати його у процесі розробки технологій, методів та навчальних посібників.

Ключові слова: емоційний інтелект, технічна освіта, компетентнісний підхід, комунікативний метод, універсальні компетентності.

Droblem statement. Preparing professional 1 specialists that are able to work effectively in the modern world is one of the important issues in the system of higher technical education in Ukraine. The specificity of modern professional activity is due to the global trends of globalization. At all stages of formation and development, from the process of higher education to further socialization, employment and career development, professionals are in the international professional community. Changes that occur in society are reflected in changes in the requirements for the process and result of training professionals. In the twenty-first century, specialists should be competent not only in solving theoretical and practical problems in their professional activities, but also able to work on solving problems within international groups to present the results of their work to the world community. However, the majority of technical higher education institutions graduates are not ready for professional activity in the current economic conditions. They often do not know how to present the results of their work, do not always monitor the development of their foreign colleagues, not only because of the poor level of Foreign Language professional communication skills, but also because of their inability to integrate into the world profession community. Foreign Language learning does not become a necessity, and this factor can lead to a decrease in their academic achievement and motivation. Thus, there are sharp contradictions among: 
- the complexity of the professional tasks faced by higher education institutions graduates and educational programs content of vocational training;

- the need for constant self-education of students and professionals and the lack of competencies they need for self-organization, self-motivation and self-control;

- the potential of the discipline «Foreign Language for Specific Purposes» in particular and in the process of implementation of educational programs in the preparation of specialists in technical fields.

These contradictions require the situation careful analysis in the higher vocational education system as a whole and the involvement of a set of pedagogical and methodological resources to solve them. The last of these contradictions led to the need for pedagogical research and selection of optimal pedagogical technologies, methodological methods and means of forming emotional intelligence precisely through the lens of discipline "Foreign Language for Specific Purposes» and made the relevance of this work.

Review of the research sources and publications. Theoretical and methodological basis of the study were general theoretical provisions of scientific psychology about: the personality essence, its formation and development patterns (V.F. Morgun, A.G. Bandura, B.G. Ananiev, L.S. Vygotsky, V.S. Merlin, V.M. Myasishchev, K.K. Platonov, S.L. Rubinstein, A.V. Petrovsky and others); on the relationship between cognitive and affective processes (D. Wexler, B.V. Zeigarnik, J. Mayer, S. Stein, etc.); provisions on personality structure (V. Morgun, G. Breslav, L. Gienko, A. Yarulov); provisions on the influence of the teacher personality on the personality formation (V. Morgun, Sh. Amonashvili, N. Berezovin, N. Radionova, D.I. Feldstein, and others). The issues of training competitive specialists have been considered in the works of Ukrainian and foreign scientists in the last decades. The future engineer professional competence purposeful formation process, including Foreign Language communicative competence, is considered from different positions.

Significant contribution to the study of "professional competence" concept was made by the works of B.S. Hershunsky, O.K. Markova, N.V. Matyash, E.M. Pavlyutenkova and others.

The problem of studying foreign languages at a higher technical school and their role in shaping the professional competence of a future non-linguistic specialist have been reflected in the research of B.V. Belyaev, I.L. Bim, G.K. Borozenets, I.A. Zimova, G.V. Rogovyi, N.L. Uvarova and others.

The theory description of communication in the professional field can be found in the works of V.P. Konetsky, E.I. Pasov, I.V. Rakhmanov, V.L. Skalkin, V.M. Tomilov, L.N. Shabalina and others.

Highlighting previously unresolved parts of the main problem. To investigate factors that can lead to successful socialization of young professionals, employment and career growth, formation and development of universal competencies of a competent specialist in Foreign Language classes.

To analyze and select modern educational technologies, implemented by means of the discipline «Foreign Language for Specific Purposes» which enable to form and develop a number of components of the universal competences necessary for a specialist to conduct successful professional activity.
The purpose of the article. The main purposes of this work are: to investigate and offer optimal pedagogical technologies, methodical methods and means of forming emotional intelligence precisely through the lens of the discipline "Foreign Language for Specific Purposes»; to analyze the factors that can lead to the successful socialization of young professionals, to investigate the factors that affect employment and career growth; to systematize the factors of universal competencies formation and development of a competent specialist in Foreign Language classes; to analyze the Foreign Language communicative competence formation of future specialists.

Basic material and results. Personal qualities, emotional intelligence and communicative competence are the most important components of a specialist's specialist competencies.

As the basic components of emotional intelligence it is considered:

- empathy;

- the ability to correctly evaluate and express their emotions correctly;

- introspection;

- ability to correctly interpret the emotions of the interlocutor;

- the ability to understand and apply ideas and current trends in the development of science and society;

Modern educational technologies, implemented by means of the discipline "Foreign Language for Specific Purposes», enable to form and develop a number of components of universal competencies necessary for a future specialist. It should be noted that the teaching of Foreign Language in higher education is carried out from the standpoint of communicative and competent approaches, which reflect the tendencies of development of modern engineering pedagogy and methods of teaching foreign languages in higher education. $\mathrm{T}$

The most effective pedagogical technologies for enhancing emotional students are:

1. personal-oriented learning technology;

2. problem-based learning technologies;

3. sign-context learning technology;

4. group training technology.

The technology of personally-oriented learning is fundamental in the formation of races of the competencies we consider, as the realization of students' personal goals, tasks and expectations allows to make the educational process as effective as possible. Person-centered Foreign Language learning involves compulsory consideration of students' outlook, the context of their future professional activity, life experiences, their status in the group [6]. The self-oriented education that is optimal for the education of students and society in general [8].

The idea of problematic learning, developed for a long time by foreign and domestic scientists, is to learn the system of knowledge in the process of independent research activities of students in the course of solving problematic situations, formulated by the teacher. It has been considered the most important functions for the formation of universal competences described by M. Mahmutov:

1. mastering the system of knowledge and methods of mental and practical activity;

2. development of cognitive independence and creative abilities; 
3. formation of a comprehensive and harmoniously developed personality;

4. application of acquired knowledge in the new situation;

5. formation of cognitive, social and affective motivation [4].

Significant in the system of higher vocational education is the technology of sign-contextual learning, bringing students as close as possible to their future professional activity and creating favorable conditions for cognitive motivation. A.A. Verbitsky, the author of this technology, rethinks the logic of the learning process in the preparation of a professional, shifting the emphasis from obtaining students abstract knowledge on the personal activity of the student, which provides the formation of the required professional qualities of a specialist [1].

The use of group learning technology enables to develop such components of emotional intelligence as empathy, recognition and correct interpretation of emotions, social motivation. [6]. In Foreign Language classes, training can be conducted in pairs, mini-groups, working groups whose composition is arbitrarily varied by the teacher. Depending on the personal characteristics of the students, the teacher, by forming groups and distributed responsibilities among their participants, can develop such important universal characteristics as responsibility, punctuality and the ability to manage.

The concept of "emotional intelligence" and the issues of its development in pedagogical and methodological studies are not sufficiently covered, so it is important to consider them in more detail. The concept of "emotional intelligence" has recently been introduced into modern science. In 1990, John Meyer and Peter Selovey began using the term to denote the ability to recognize their own emotions and those of others [8; 9]. The notion of emotional intelligence has gained a great deal of popularity thanks to Daniel Goleman. The scientist identifies the following components of emotional intelligence:

1) self-awareness - the ability to recognize and name their own feelings;

2) motivation - the ability to continue acting despite failures;

3) self-regulation - the ability to control their emotions;

4) empathy - the ability to understand the feelings of others;

5) complicity - the ability to understand and correctly interpret other people's feelings for success in communication [2].

People with high levels of emotional intelligence find solutions to the problem and cope with any dif- ficult situations much faster. With regard to the educational process in higher education, it should be noted that only a graduate with a sufficiently high level of emotional intelligence, who has the concept of "emotional literacy", is able to become a high-level specialist, competitive specialist.

The above pedagogical technologies enable to develop the emotional intelligence of students in the process of vocational training, provided they are aware of the importance of this component of universal competences for the formation of professional competence. The leading approach to learning foreign languages is a communicative approach, and the Foreign Language teacher has a whole arsenal of means for developing not only the cognitive but also the emotional intelligence of students.

Conclusions and suggestions. Consideration of universal competences in a technical institution of higher education by means of discipline "Foreign Language for Specific Purposes», the following conclusions from the conducted research are:

1. A professional of the new generation must not only possess a set of certain professional knowledge, skills and skills, but also be a mature, responsible, creative personality with an active life position.

2. One of the most important components of professional competence in terms of increasing competitiveness is the emotional intelligence of a university graduate.

3. The current situation necessitates the maximum use of the discipline «Foreign Language for Specific Purposes» potential in the educational process to increase the level of emotional intelligence of the future specialist for effective future activity.

4. The valuable experience gained by foreign and Ukrainian psychologists, educators and methodologists in the field of Foreign Language teaching should be considered in approaches, principles, technologies, methods and teaching aids.

5 . The technologies of personality-oriented learning, problem learning, sign-contextual learning and group learning promote the emotional intelligence formation, development and improvement.

6. The optimal solution to achieve this goal is the complementary didactic resources use along with the creation of interdisciplinary projects integrated into the specialist training system, which requires separate consideration by psychologists, educators, methodologists and managers of the educational process.

Increasing the emotional intelligence of future specialists in technical higher education institutions contributes to the integration of Ukrainian professionals into the world community strengthening Ukraine position in the world community.

\section{References:}

1. Verbitskiy A.A. (2004). Kompetentnostnyy podkhod i teoriya kontekstnogo obucheniya [Competency Approach and Theory of Contextual Learning]. Moscow: Logos. (in Russian)

2. Goulman D. (2014). Emotsional'nyy intellekt. Pochemu on mozhet znachit' bol'she, chem IQ [Emotional intellect. Why can it mean more than IQ]. Moscow: Mann, Ivanov i Ferber. (in Russian)

3. D'yachenko V.K. (2004). Kollektivnyy sposob obucheniya. Didaktika $v$ dialogak [The collective way of learning. Didactics in dialogs]. Moscow: Narodnoye Obrazovaniye. (in Russian)

4. Passov E. I. (1991). Kommunikativnyy metod obucheniya inoyazychnomu govoreniyu: posobiye dlya uchiteley inostrannykh yazykov [A communicative method of teaching foreign language speaking: a manual for teachers of foreign languages]. Moscow: Prosveshcheniye. (in Russian)

5. Salnaya L.K. (2009). Obuchenie professionalno orientirovannomu inoyazychnomu obsheniyu [Training in professionally oriented foreign language communication]. Taganrog: TTI YuFU. (in Russian)

6. Shiyan T.V. (2012). Rozvytok Emotsiinoho Intelektu Studentiv Molodshykh Kursiv Zasobamy Dystsypliny «Anhliiska Mova Za Profesiinym Spriamuvanniam» [Development of emotional intelligence of junior students 
by means of the discipline "English for Professional Purpose"]. Naukovi Pratsi naukovo-pedahohichnyi zhurnal, vol. 199 , no. 187 , pp. 92-96.

7. Mayer J. D., Salovey P. (1993). The Intelligence of Emotional Intelligence. New York: Cambridge University Press.

\section{Список літератури:}

1. Вербицкий А.А. Компетентностный подход и теория контекстного обучения. Москва, 2004. 84 с.

2. Гоулман Д. Эмоциональный интеллект. Почему он может значить больше, чем IQ. Москва, 2014.560 с.

3. Дьяченко В.К. Коллективный способ обучения. Дидактика в диалогах. Москва, 2004. 352 с.

4. Пассов Е.И. Коммуникативный метод обучения иноязычному говорению : пособие для учителей иностранных языков. Москва, 1991. 223 с.

5. Сальная Л.К. Обучение профессионально ориентированному иноязычному общению. Таганрог : Изд-во ТТИ ЮФУ, 2009. 198 с.

6. Шиян Т.В. Розвиток емоційного інтелекту студентів молодших курсів засобами дисципліни «Англійська мова за професійним спрямуванням». Миколаїв, 2012. Вип. 187. Т. 199. С. 92-96.

7. Mayer J.D., Salovey P. The Intelligence of Emotional Intelligence. New York, 1993. P. 433-442. 